\title{
Design of a Synthetic Zinc Oxide Catalyst over Nano- Alumina for Sulfur Removal by Air in a Batch Reactor
}

\author{
Amer T. Nawaf ${ }^{1,4, *}$, Aysar T. Jarullah ${ }^{2,5}$, Layth T. Abdulateef ${ }^{3}$ \\ ${ }^{I}$ Chemical Engineering, College of Petroleum \& Minerals Engineering, Tikrit University, Iraq \\ ${ }^{2}$ Chemical Engineering Department, College of Engineering, Tikrit University, Iraq \\ ${ }^{3}$ Chemical Engineering, Middle Technical University, Iraq
}

Received: $16^{\text {th }}$ April 2018; Revised: $26^{\text {th }}$ September 2018; Accepted: $30^{\text {th }}$ September 2018; Available online: $25^{\text {th }}$ January 2019; Published regularly: April 2019

\begin{abstract}
Owing to the environmental regulations with respect to sulfur content and continuing challenges of finding a suitable catalyst of such impurity, a driving force for the development of more efficient technologies a deep research on new oxidative catalysts is considered an important issue in fuel quality improvement. Thus, the present study shows a novel percent of nano-catalyst with $18 \%$ zinc oxide $(\mathrm{ZnO})$ of active component over nano-alumina that has not been reported in the public domain for sulfur removal from kerosene fuel by air (oxidative desulfurization (ODS) method). Where, such percent of the active component on the nano-alumina helps to add one or two atoms of oxygen to sulfur content in the kerosene. The nano-catalyst ( $\mathrm{ZnO} /$ nano-alumina-particles composite) is prepared by precipitation of zinc oxide and loaded over nano-alumina in one-step. The activity of the prepared catalyst was tested utilizing ODS process of kerosene fuel by air in a batch reactor. A set of experiments were conducted with a wide range of operating conditions, where the reaction temperature was ranged from 150 to $190^{\circ} \mathrm{C}$, the reaction time from 30 to $50 \mathrm{~min}$ and the catalyst weight from 0.4 to $1 \mathrm{~g}$. The experimental results showed that the chemical nature of zinc oxides showed higher conversion (70.52\%) at reaction temperature of $190{ }^{\circ} \mathrm{C}$, reaction time of 50 min, and $1 \mathrm{~g}$ catalyst weight used in the batch reactor. A kinetic model related to the sulfur removal from kerosene via ODS process in the batch reactor was also investigated in this study for the purpose of estimating the best kinetic parameters of the relevant reactions. The results showed that the prepared catalyst (ZnO over nanoalumina) can be applied confidently to reactor design, operation and control in addition to improve the fuel quality. Following the kinetic model of ODS process, a very well agreement between the experimental and predicted results is obtained. Copyright (C) 2019 BCREC Group. All rights reserved
\end{abstract}

Keywords: Nano-Catalyst; Oxidative Desulfurization; Zinc Oxide; Kerosene; Batch Reactor

How to Cite: Nawaf, A.T., Jarullah, A.T., Abdulateef, L.T. (2019). Design of a Synthetic Zinc Oxide Catalyst over Nano-Alumina for Sulfur Removal by Air in a Batch Reactor. Bulletin of Chemical Reaction Engineering \& Catalysis, 14 (1): 79-92 (doi:10.9767/bcrec.14.1.2507.79-92)

Permalink/DOI: https://doi.org/10.9767/bcrec.14.1.2507.79-92

\section{Introduction}

Recently, the main goal of the current decade related to the environmental legislations across the world is to reduce the total sulfur content in feedstock of transportation fuels [1]. These regu-

* Corresponding Author.

E-mail: amer.talal@tu.edu.iq (A.T. Nawaf), a.t.jarllah@tu.edu.iq (A.T. Jarullah)

Telp: +964-7707972146; +964-7706688809 lations were reported that the maximum sulfur content should not be currently exceeded 0.005 wt\%, and less than $0.0015 \mathrm{wt} \%$ or nil (freesulfur content) in the coming years [2-4]. The main source of air pollution is attributed to the generation of sulfur oxides by the combustion process leading to form acid rain. The oxidation desulfurization process used for removal all types of sulfur in fuel is expected to solve great environmental problems occurring wherever different petroleum fractions are used [5]. The 
catalytic hydrodesulfurization (HDS), which is commonly known as hydrotreating process requires modified catalyst, higher operating conditions (temperature, pressure, etc.) and toxic emissions may be generated due to the combustion of these fuels producing many gases [6].

A new sulfur removal technology without needing to use hydrogen $\left(\mathrm{H}_{2}\right)$ is the oxidation process (ODS) for catalytic decomposition of organosulfur compounds, which are classified as a non-hydrodesulphurization process (HDS) and adopted as ultra-deep desulfurization for many petroleum fractions. Organosulfur compounds in fuel will be converted to sulfone using a percent of oxygen or air directly rather than hydrogen and such process is considered an attractive issue in petroleum refining industries due to the availability of the reacting gas (air) and its low price in addition to safe operating conditions used. Where, the reaction temperature is ranged from $40-100{ }^{\circ} \mathrm{C}$ and the pressure is ranged from 1-2 bar and sometimes such process can be applied at room temperature and atmospheric pressure leading to reduce the operating cost compared with HDS process [7-11].

The ODS process is objected to oxidize sulfur compounds corresponding to sulfides or sulfones by adding electrophilic oxygen atom found in air giving a polar form and becoming as non-active compounds that can be removed by extraction or desorption process [12]. Ma et al. [13] studied the sulfur removal from different types of commercial jet fuel by oxidant molecular oxygen at moderate conditions using several sulfur models of jet fuel (BT, 2-MBT, 5MBT and DBT dissolved in $\mathrm{n}$-decane). They found that the sulfur content can be reduced by adsorption $\mathrm{Fe}$ (III) nitrate and $\mathrm{Fe}(\mathrm{III})$ bromide. Sundaraman et al. [4] have applied the ODS process of commercial jet fuel with sulfur content of $0.052 \mathrm{wt} \%$ and commercial diesel fuel with sulfur content at $0.0041 \mathrm{wt} \%$ using air as an oxidant for generating hydro-peroxides with $\mathrm{CuO}$ as a catalyst. The Authors have reported that the sulfur compounds in jet and diesel fuel are oxidized to sulfones with $\mathrm{MoO}_{3} / \mathrm{SiO}_{2}$ then the formed sulfones were adsorbed by beta zeolite to ultra-low sulfur jet and diesel fuel.

Javadli et al. [14] utilized the oxidative desulfurization of the model feedstock (dibenzothiophene in bitumen) using air as an oxidant for generation sulfone or sulfoxide in bitumen. N-heptane have employed to prevent the bitumen hardening during autoxidation process based on $\mathrm{H}_{2} \mathrm{O}$ used for washing step and they found that the sulfur removal is achieved by $46-47 \%$.
Imtiaz et al. [15] have studied the ODS of sulfur for different feedstock models (thiophene, dibenzothiophene, 4-MDBT) using air/quaternary ammonium salt as oxidant. They found that an increase in temperature process, the rate of removal of sulfur increased rapidly. Nawaf et al. [16] employed the ODS of DBT in light gas oil (LGO) using several initial DBT contents, liquid hourly space velocities and different reactor temperatures in a trickle bed reactor (TBR) based on a prepared catalyst of manganese oxide $\left(\mathrm{MnO}_{2} / \gamma-\mathrm{Al}_{2} \mathrm{O}_{3}\right)$, and high sulfur removal was observed.

Nada et al. [17] have examined the ODS process of kerosene based on $\mathrm{ZnO} / \mathrm{AC}$ composite prepared by thermal co-precipitation method in a batch system using air as oxidant. The highest conversion of sulfur is about $33 \%$ at optimum operating conditions. Thus, this work is aimed to prepare a new nano-catalyst (zinc oxide loaded on alumina nano-particles) for the purpose of testing the possibility of sulfur removal from kerosene utilizing the oxidation desulfurization process (ODS) in a batch system by air as an oxidant. Also, the kinetic model of the oxidative desulfurization process of such reactor is investigated here for further insight of the process.

\section{Materials and Method}

Kerosene feedstock with sulfur content of $2500 \mathrm{ppm}(0.25 \mathrm{wt} \%)$ was supplied by the $A L$ Dura Refinery Company-Iraq. The physical properties of the kerosene used in this study are illustrated in Table 1. Nano-alumni particles were supplied by Skyspring/USA, zinc acetate $\mathrm{C}_{4} \mathrm{H}_{8} \mathrm{O}_{4} \mathrm{Zn} .2 \mathrm{H}_{2} \mathrm{O}$ with purity of $99 \%$ and deionized water were supplied by Sinopharm Chemical Reagent. The materials and the specifications of the catalyst used are shown in Table 2.

Various conditions are tested here for oxidtive desulfurization of kerosene as follow: (a) catalyst prepared (nano-catalyst $=18 \% \mathrm{ZnO} /$ nano- $\left.\gamma-\mathrm{Al}_{2} \mathrm{O}_{3}\right)$; (b). reaction time (30 $\mathrm{min}, 40$ $\mathrm{min}$, and $50 \mathrm{~min}$ ); (c). reaction temperature $\left(150{ }^{\circ} \mathrm{C}, 170{ }^{\circ} \mathrm{C}\right.$, and $\left.190{ }^{\circ} \mathrm{C}\right)$; (d). weight of catalyst $(0.4 \mathrm{~g}, 0.7 \mathrm{~g}$, and $1 \mathrm{~g})$.

\subsection{Catalyst Preparation (18\% ZnO/Nano- $\gamma$ - $\mathrm{Al}_{2} \mathrm{O}_{3}$ )}

Zinc oxide loaded as active component on nano-alumina particles composite is prepared by a thermal co-precipitation method. The nano-alumina particles are dried in an oven for $1.5 \mathrm{~h}$ at $250{ }^{\circ} \mathrm{C}$ to remove the moisture out of the support pores of alumina. An amount of $8 \mathrm{~g}$ 
by weight of nano-alumina particles is used as the active component. Meanwhile, $4 \mathrm{~g}$ of zinc acetate salt was dissolved in $50 \mathrm{~mL}$ of deionized water and mixed for $2.5 \mathrm{~h}$ to obtain a good dissolving with the salt, where such quantity can

Table 1. Kerosene properties

\begin{tabular}{|c|c|}
\hline Property & Value \\
\hline Density at $15.6^{\circ} \mathrm{C}$ & $0.82-0.86 \mathrm{~g} / \mathrm{cm}^{3}$ \\
\hline API & 47.6 \\
\hline Flash point & 54 \\
\hline $\begin{array}{c}\text { Kinematic viscosity at } \\
40{ }^{\circ} \mathrm{C}(\mathrm{cSt})\end{array}$ & $2.5-5.6$ \\
\hline Water content\% Vol. & $0.05 \max$ \\
\hline Color & $>+30$ \\
\hline Sulfur Content & $0.25 \% \mathrm{wt}$ \\
\hline Smoke Point & 28 \\
\hline Ash content $\%$ wt & $0.01 \max$ \\
\hline Pour point ${ }^{\circ} \mathrm{C}$ & $\begin{array}{l}\text {-9 max Winter } \\
-3 \text { max Summer }\end{array}$ \\
\hline \multicolumn{2}{|l|}{ Distillation Data $\left({ }^{\circ} \mathrm{C}\right)$} \\
\hline Initial Boiling point & 163 \\
\hline $10 \%$ & 179 \\
\hline $20 \%$ & 184 \\
\hline $30 \%$ & 190 \\
\hline $40 \%$ & 194 \\
\hline $50 \%$ & 198 \\
\hline $60 \%$ & 203 \\
\hline $70 \%$ & 209 \\
\hline $80 \%$ & 215 \\
\hline $90 \%$ & 224 \\
\hline End Point & 246 \\
\hline
\end{tabular}

give 18 wt $\%$ of $\mathrm{ZnO}$ on Nano- $\gamma-\mathrm{Al}_{2} \mathrm{O}_{3}$ loaded. Then, zinc acetate solution prepared is slowly added on the Nano-alumina particles under continuous mixing and without heating. The prepared mixture was heated for $2 \mathrm{~h}$ in the oven at $125{ }^{\circ} \mathrm{C}$ for $5{ }^{\circ} \mathrm{C} / \mathrm{min}$ with laminar air flow. After that, the mixture is firstly heated at $250{ }^{\circ} \mathrm{C}$ for $2 \mathrm{~h}$ and the temperature is then increased to $400{ }^{\circ} \mathrm{C}$ for $1 \mathrm{~h}$ to get a well drying of the mixture. Finally, the mixture is heated up to $560{ }^{\circ} \mathrm{C}$ for $2 \mathrm{~h}$ where the metal oxides are loaded on the supported nano-alumina followed gradually by a cooling process. The calcination procedure (as shown in Figure 1) has been conducted in Hadithah Diesel Power Plant-AlAnbar-Iraq.

\subsection{Experimental Procedure for ODS Process}

The oxidative desulfurization experiments were carried out into batch reactor $(250 \mathrm{~mL})$ using kerosene as a feedstock and air as oxidant for oxidative desulfurization reactions. In all experiments, $100 \mathrm{~mL}$ of kerosene has charged for each run. The air flow rate in ODS reactions was $0-3 \mathrm{~L} / \mathrm{h}$ with keeping constant pressure at 0.5 bar. The prepared catalyst was charged to the batch reactor containing the liquid feedstock (kerosene), where the ODS reactions are carried out. Several experiments were carried out under moderate operating conditions (reaction temperatures $\left(150{ }^{\circ} \mathrm{C}, 170{ }^{\circ} \mathrm{C}\right.$, and $190^{\circ} \mathrm{C}$ ), reaction time (30 $\mathrm{min}, 40 \mathrm{~min}$, and $50 \mathrm{~min})$ and catalyst weight $(0.4 \mathrm{~g}, 0.7 \mathrm{~g}$, and 1 g) with keeping constant stirring rate used for all experiments at $500 \mathrm{rpm}$ for the purpose of obtaining a good mixing and avoiding segregation of both fluid and catalyst [18]. The evaporated gases during the oxidation reactions are

Table 2. Materials and specifications of the catalyst used

\begin{tabular}{cc}
\hline & Materials \\
\hline Chemical Properties of Zinc Acetate & \\
Chemical Structure & $\mathrm{C}_{4} \mathrm{H}_{8} \mathrm{O}_{4} \mathrm{Zn}_{2} . \mathrm{H}_{2} \mathrm{O}$ \\
Molecular Weight & 219.51 \\
Purity & $\geq 99.0 \%$ \\
$\mathrm{PH}\left(50 \mathrm{~g} / \mathrm{L}, 25^{\circ} \mathrm{C}\right)$ & $6.0-7.0$ \\
Typical Impurities & $\mathrm{Cl} \leq 0.001 \%, \mathrm{SO}_{2} \leq 0.002 \%, \mathrm{Fe} \leq 0.003 \%, \mathrm{As} \leq 0.00002 \%, \mathrm{~Pb} \leq 0.002 \%$ \\
Specifications of Alumina Nano Particles & \\
Appearance & White \\
Empirical formula & $\gamma-\mathrm{Al}_{2} \mathrm{O}_{3}$ \\
Purity & $20 \mathrm{~nm}$ \\
APS & $299.9 \%($ trace metal basis $)$ \\
Typical Impurities & $\mathrm{Si}=20 \mathrm{ppm}, \mathrm{Na}=10 \mathrm{ppm}, \mathrm{K}=10 \mathrm{ppm}, \mathrm{Ca}=20 \mathrm{ppm} \mathrm{Fe}=20 \mathrm{ppm}$ \\
\hline
\end{tabular}




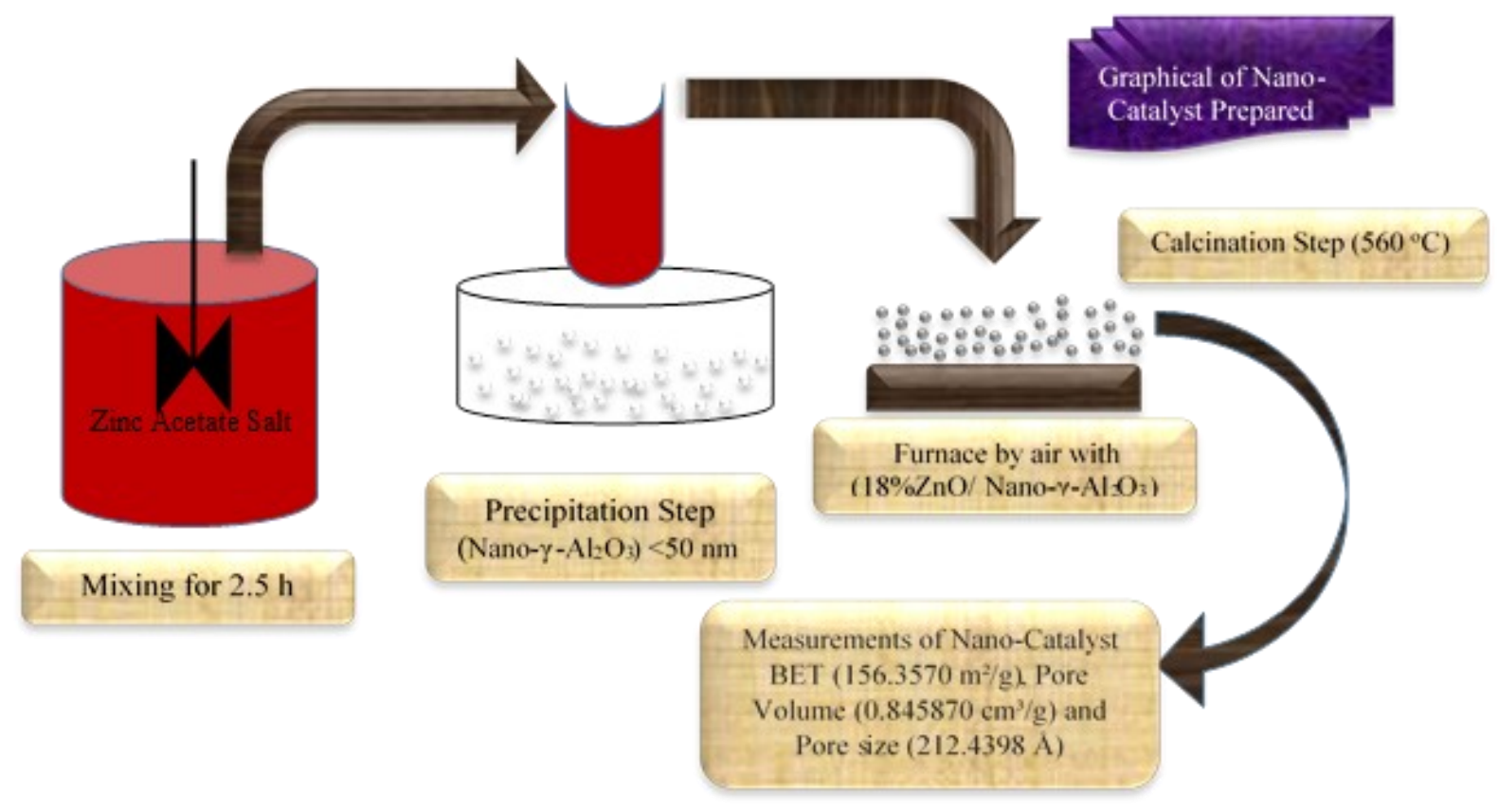

Figure 1. Calcination procedure

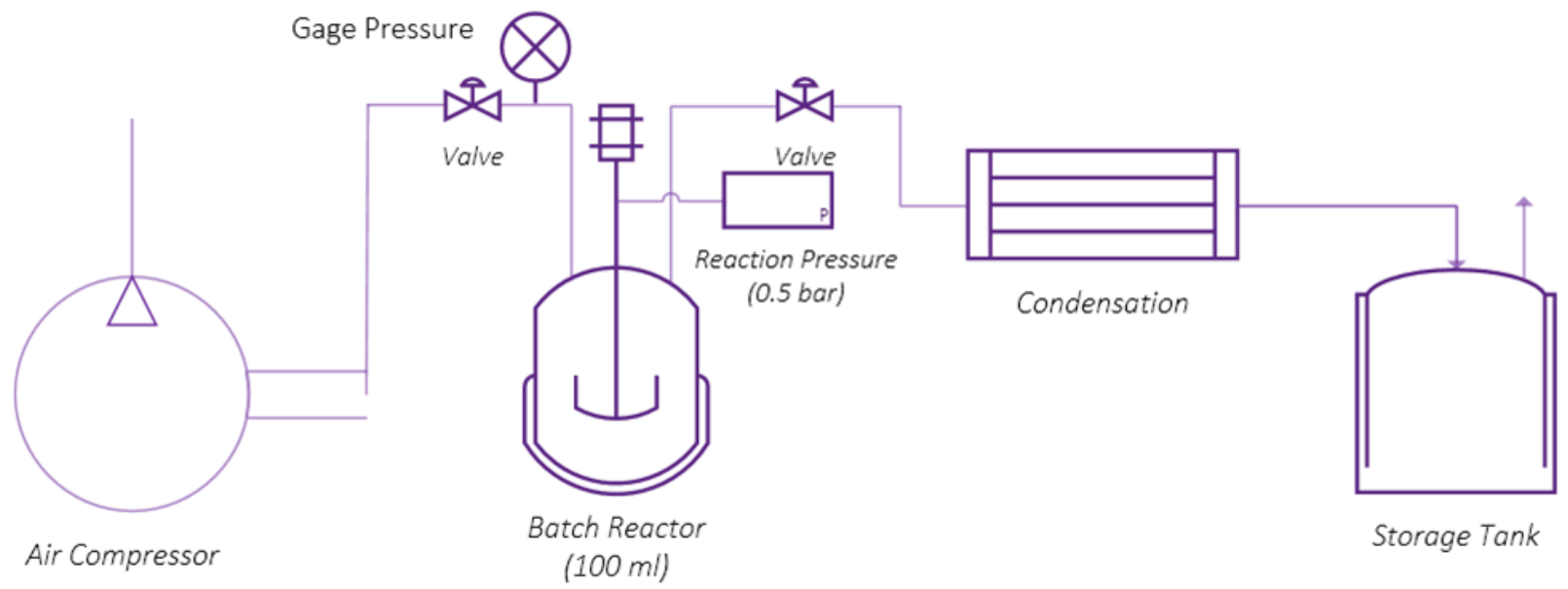

Figure 2. Flow sheet of pilot plant experiments

Table 3. BET Surface Area report

\begin{tabular}{ccc}
\hline $\begin{array}{c}\text { Relative } \\
\text { Pressure } \\
(\mathrm{P} / \mathrm{P})\end{array}$ & $\begin{array}{c}\text { Quantity } \\
\text { Adsorbed } \\
(\mathrm{mmole} / \mathrm{g})\end{array}$ & $1 /[\mathrm{Q}((\mathrm{P} / \mathrm{P} \circ)-1)]$ \\
\hline 0.047871918 & 1.55927 & 0.03225 \\
0.067195243 & 1.63970 & 0.04393 \\
0.079264912 & 1.68350 & 0.05114 \\
0.112400545 & 1.78863 & 0.07080 \\
0.119981888 & 1.81134 & 0.07527 \\
0.159932984 & 1.92126 & 0.09909 \\
0.174993727 & 1.96092 & 0.10817 \\
0.200006303 & 2.02487 & 0.12347 \\
0.237219632 & 2.12231 & 0.14654 \\
0.299716818 & 2.28830 & 0.18704 \\
\hline
\end{tabular}

Table 4. Isotherm tabular

\begin{tabular}{cccc}
\hline $\begin{array}{c}\text { Relative } \\
\text { Pressure } \\
\left(\mathrm{P} / \mathrm{P}^{\circ}\right)\end{array}$ & $\begin{array}{c}\text { Absolute } \\
\text { Pressure } \\
(\mathrm{kPa})\end{array}$ & $\begin{array}{c}\text { Quantity } \\
\text { Adsorbed } \\
(\mathrm{mmole} / \mathrm{g})\end{array}$ & $\begin{array}{c}\text { Elapsed } \\
\text { Time } \\
(\mathrm{h}: \mathrm{min})\end{array}$ \\
\hline 0.047871918 & 4.8884007 & 1.55927 & $01: 38$ \\
0.067195243 & 6.8615858 & 1.63970 & $01: 41$ \\
0.079264912 & 8.0940699 & 1.68350 & $01: 44$ \\
0.112400545 & 11.4776873 & 1.78863 & $01: 46$ \\
0.119981888 & 12.2518497 & 1.81134 & $01: 49$ \\
0.159932984 & 16.3314224 & 1.92126 & $01: 52$ \\
0.174993727 & 17.8693374 & 1.96092 & $01: 54$ \\
0.200006303 & 20.4234757 & 2.02487 & $01: 57$ \\
0.237219632 & 24.2234835 & 2.12231 & $01: 59$ \\
0.299716818 & 30.6053311 & 2.28830 & $02: 02$ \\
0.979436866 & 100.0143730 & 24.39765 & $02: 56$ \\
\hline
\end{tabular}


condensed through the condensation supplied to the process. Product sulfur concentrations were analyzed via X-ray diffraction instrument based on ASTM D7039 method. The product sulfur content of kerosene was determined in AL-Dura Power Station Laboratories/Ministry of Electricity-Iraq. Process flow diagram of the batch reactor system is illustrated in the Figure 2.

\subsection{Characterization of Nano-Catalyst Prepared}

The amount of the active component (metal oxide) used for preparing the nano-catalyst from zinc oxide via composite zinc acetate was tested by BET surface area, pore volume and pore size. Determination of the prepared nanocatalyst particles has been carried out at The Petroleum Research and Development Center/Ministry of Oil-Iraq. The data obtained with respect to surface area of the nanocatalyst is shown in the Table 3 and illustrated in Figure 3. Operation conditions of the process analysis are as follow: analysis adsorptive of $\mathrm{N}_{2}$; analysis bath temperature of $77.441 \mathrm{~K}$; warm free space of $28.8645 \mathrm{~cm}^{3}$; and equilibration interval of $10 \mathrm{~s}$.

Langmuir surface area as an isotherm for gases adsorbed on the solid particles has also been estimated, which is an empirical isotherm derived from a proposed kinetic mechanism. It is based on the surface of the adsorbent as uniform, where all the adsorption sites are equals and the adsorbed molecules should not be intersected with each other. At maximum adsorp-

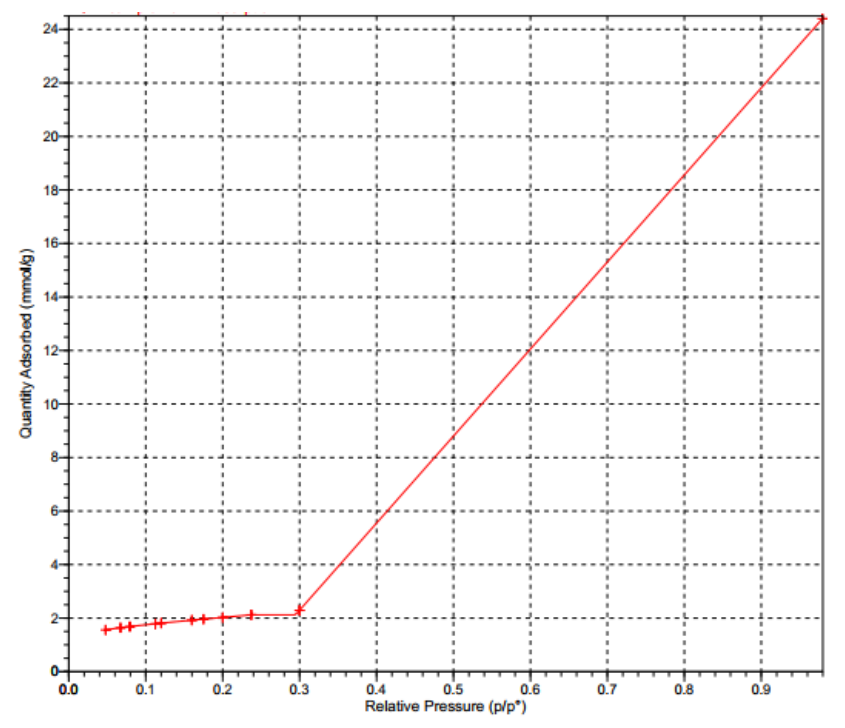

Figure 3. Isotherm data of the prepared nanocatalyst tion, a monolayer is formed and the molecules of the adsorbate are not deposited on other sites, but the molecules will be adsorbed on the free surface of the adsorbent only. The obtained isotherm tabular data of the prepared nano-catalyst is reported in the Table 4.

\subsection{Mathematical Modelling of ODS Reactions}

\subsubsection{Model based on kinetics of oxidation} desulfurization

Kinetics model related to the oxidative desulfurization process is studied here based on oxygen as oxidant and $\mathrm{ZnO} / \mathrm{nano}-\gamma-\mathrm{Al}_{2} \mathrm{O}_{3}$ catalyst including the pseudo first and second order kinetics, external diffusion model and intra particle diffusion model, which are expressed within the kinetic rate equation to find the best kinetic model through the comparison among correlation coefficients.

Mole balance in the batch reactor for desulfurization:

$$
\begin{aligned}
\text { Mole in }= & \text { Mole out }+ \text { Accumulation } \\
& + \text { Dissapparance by chemical reaction } \\
\text { Mole in }= & \text { Mole out }=0 \text { (in the batch reactor })
\end{aligned}
$$

Substitution of Eq. (2) into Eq. (1) results in: Accumulation $=-($ Dissapparance by reaction $)$

Accumulation $=\left(-r_{\text {sulfur }}\right)\left(V_{\text {Batch }}\right)$

Dissapparance by reaction $=\frac{d N_{\text {sulfur }}}{d t}$

From Equations (3), (4), and (5), Eq. (6) becomes:

$$
-\frac{d N_{\text {sulfur }}}{d t}=\left(-r_{\text {sulfur }}\right)\left(V_{\text {Batch }}\right)
$$

At constant density,

$$
\begin{aligned}
& -\frac{d\left(\frac{N_{\text {sulfur }}}{V_{\text {Batch }}}\right)}{d t}=\left(-r_{\text {sulfur }}\right) \\
& -\frac{d C_{\text {sulfur }}}{d t}=\left(-r_{\text {sulfur }}\right)
\end{aligned}
$$

The chemical reaction rate equation is stated as follows:

$$
\begin{aligned}
& \text { For Pseudo first order }=\left(-r_{A}\right)=K C_{\text {sulfur }} \\
& -\int_{C_{\text {sulfur }(0)}}^{C_{\text {sulfur }(f)}} \frac{d C_{\text {sulfur }}}{C_{\text {sulfur }}}=\int_{0}^{t} K d t \\
& \ln \frac{C_{\text {sulfur }(0)}}{C_{\text {sulfur }(f)}}=K t
\end{aligned}
$$

For Pseudo second order $=\left(-r_{A}\right)=K C_{\text {sulfur }}^{2}$ 
Thus,

$$
\begin{aligned}
& -\int_{C_{\text {sulfur }(0)}}^{C_{\text {sulfur }(f)}} \frac{d C_{\text {sulfur }}}{C_{\text {sulfur }}^{2}}=\int_{0}^{t} K d t \\
& \frac{1}{C_{\text {sulfur }(f)}}=\frac{1}{C_{\text {sulfur }(0)}}+K t
\end{aligned}
$$

2.4.2 Pore diffusion in the prepared catalyst $\left(18 \% \mathrm{ZnO} /\right.$ nano- $\left.\gamma-\mathrm{Al}_{2} \mathrm{O}_{3}\right)$

Studying the effect of air and sulfur mass transfer in kerosene for oxidative desulfurization process inside pore catalyst prepared $\left(\mathrm{ZnO} /\right.$ nano- $\left.\gamma-\mathrm{Al}_{2} \mathrm{O}_{3}\right)$ is calculated through the Thiele modulus $\left(M_{T}\right)$ as presented in the following equation [19]:

$$
M_{T}=L\left(\frac{K(n+1) C_{\text {sulfur }}^{(n-1)}}{2 D_{E f f}}\right)^{\left(\frac{1}{2}\right)}
$$

For second order kinetic reaction:

$$
-r_{\text {sulfur }}=K C_{\text {sulfur }}^{2}
$$

Hence:

$$
M_{T}=L\left(\frac{3 K C_{\text {sulfur }}}{2 D_{\text {Eff }}}\right)^{\left(\frac{1}{2}\right)}
$$

Effective diffusivity $\left(D_{E f f}\right)$ can be determined as follows:

$$
D_{E f f}=\frac{D_{A B} \in_{P}}{\tau_{P}}
$$

In this work, the $\mathrm{ZnO} /$ nano- $\gamma-\mathrm{Al}_{2} \mathrm{O}_{3}$ catalyst have been assumed to be as sphere particles. So, the porosity $\epsilon_{P}$ can be estimated depending on the experiments of the total pore volume, while, the tortuosity was found to be 1.978 $[20,21]$. The molecular diffusion coefficient $\left(D_{A B}\right)$ of the air in kerosene is estimated to be $0.0495 \mathrm{~cm}^{2} / \mathrm{s}$ at $67{ }^{\circ} \mathrm{C}$ and equals to 0.5789 $\mathrm{cm}^{2} / \mathrm{s}$ at $25{ }^{\circ} \mathrm{C}$ [22]. The diffusivity function with temperature can be stated as:

$$
\frac{D_{A B}}{D_{A B 0}}=\left(\frac{T, K}{T_{0}, K}\right)^{1.5}
$$

\section{Results and Discussion}

\subsection{Catalyst Characterizations}

\subsubsection{BET surface area (ASTM D5604)}

The surface area of the prepared nanocatalyst $18 \% \mathrm{ZnO} /$ nano- $\gamma-\mathrm{Al}_{2} \mathrm{O}_{3}$ composite was measured by BET method. The values of the surfaces area, pore size and pore volume are listed in Table 5. The surface area of nano catalyst decreases after loading metal oxide on the catalyst supported approximately by $18 \%$ (weight percent) from zinc oxide, but such surface area of $18 \% \mathrm{ZnO} / \mathrm{nano}-\gamma-\mathrm{Al}_{2} \mathrm{O}_{3}$ is still high. It can be observed based on the results obtained before and after preparation process that the surface area can close to that of the original source. Occasionally, the surface area and pore volume increases or be the same as the original source in case of loading ratio less or equals to $10 \mathrm{wt} \%$ due to a good dispersion of the metals oxides on the supported area [18].

Among the physical and chemical properties of the prepared nano catalyst, the specific surface area of $18 \% \mathrm{ZnO} /$ nano- $\gamma-\mathrm{Al}_{2} \mathrm{O}_{3}$ is an important factor affecting the catalytic activity. As the specific surface area of the catalyst preparation increases, the number of effective active site increased leading to increase the oxidation process of the reaction rate. The BET specific surface areas of the prepared catalyst and the Langmuir surface areas are shown in the Tables (3) and (4), respectively. The specific surface area is significantly dependent on the calcination temperature used during the catalyst preparation. The optimal specific surface area is found by increasing the calcination temperature up to $580{ }^{\circ} \mathrm{C}$, but an increase in such calcination temperature above $600{ }^{\circ} \mathrm{C}$ a decrease in the surface area is observed. Such behavior can be attributed to decrease in the pore volume by increasing the calcination temperature owing to the melting of metals oxide upon the surface of the catalyst at high calcination temperature [24].

Table 5. Specification of nano-supported and nano-catalyst prepared

\begin{tabular}{lcc}
\hline \multicolumn{1}{c}{ Specification } & $\mathrm{Nano}-\gamma-\mathrm{Al}_{2} \mathrm{O}_{3}$ & $18 \% \mathrm{ZnO} / \mathrm{nano}-\gamma-\mathrm{Al}_{2} \mathrm{O}_{3}$ \\
\hline Surface area & $180-200 \mathrm{~m}^{2} / \mathrm{g}$ & $159.2676 \mathrm{~m}^{2} / \mathrm{g}$ \\
Langmuir surface area & $245.5 \mathrm{~m}^{2} / \mathrm{g}$ & $223.6012 \mathrm{~m}^{2} / \mathrm{g}$ \\
Pore volume & - & $0.845870 \mathrm{~cm}^{3} / \mathrm{g}$ \\
Pore size & - & $212.4398 \AA$ \\
Catalyst nano particle & - & $20 \mathrm{~nm}$ \\
\hline
\end{tabular}




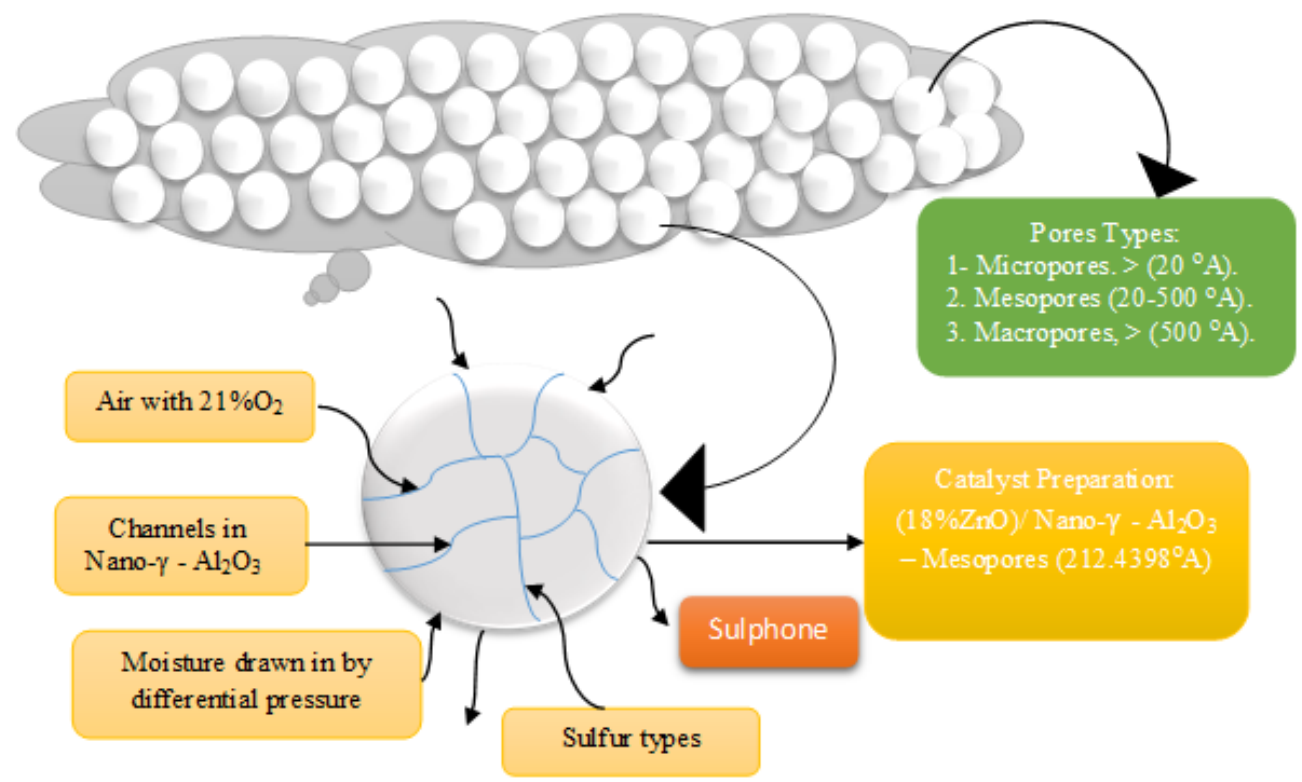

Figure 4. Chemical reactions occur in pore size distribution

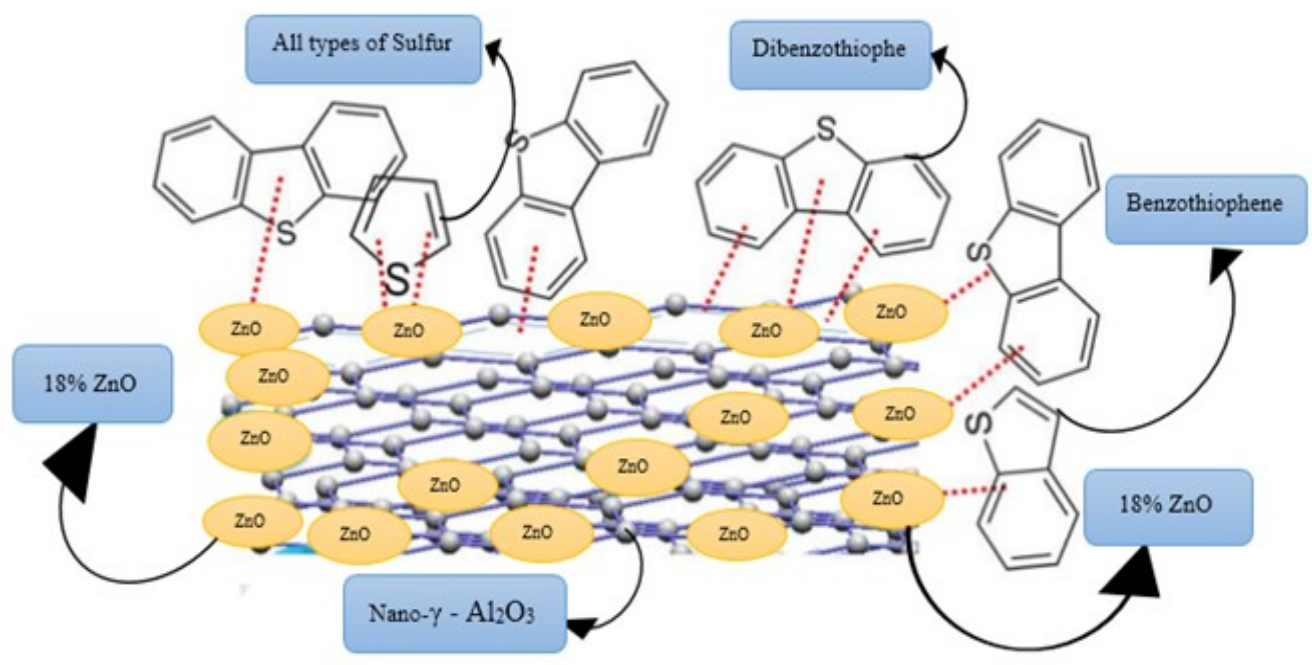

Figure 5. Distribution of metal oxide

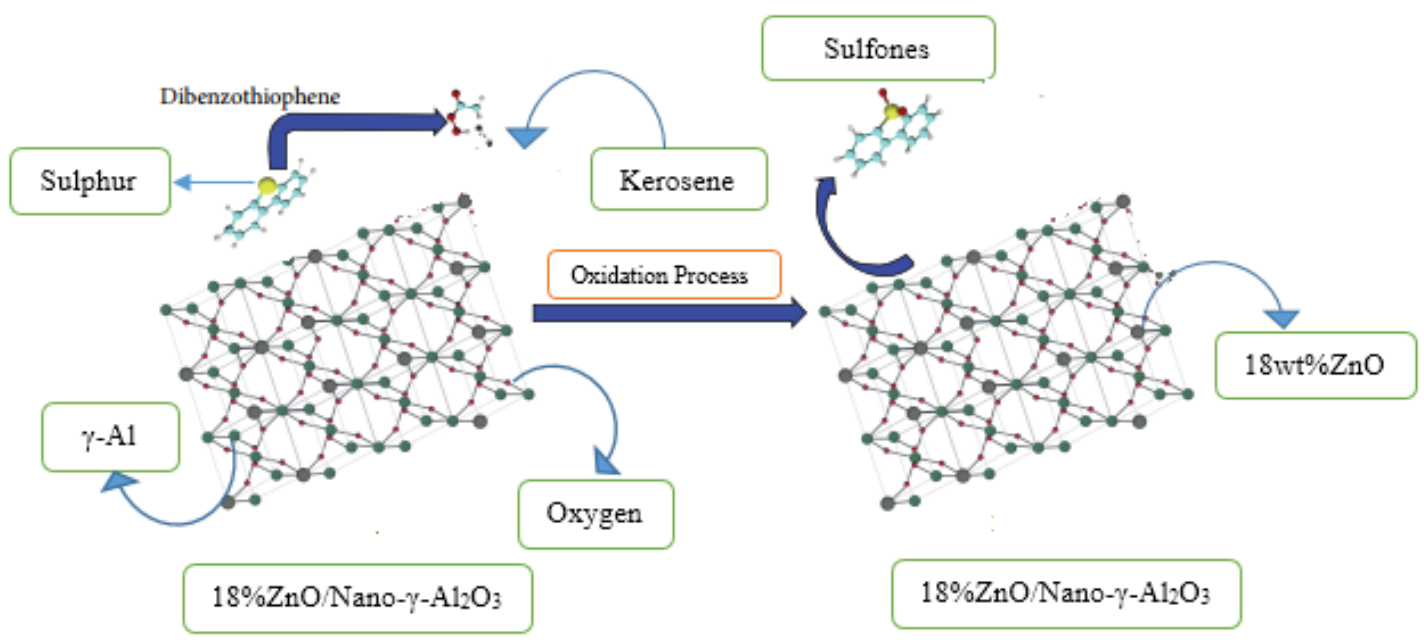

Figure 6. Oxidation desulfurization process steps in kerosene 
3.1.2 Pore size distribution (ASTM D4641) and pore volume (ASTM ISO 9277)

Catalyst pore size distribution $(\AA)$ structure estimates how easily the reactants can access the interior surface of the catalyst that has been determined by $\mathrm{N}_{2}$ desorption measurement at The Petroleum Research and Develop-
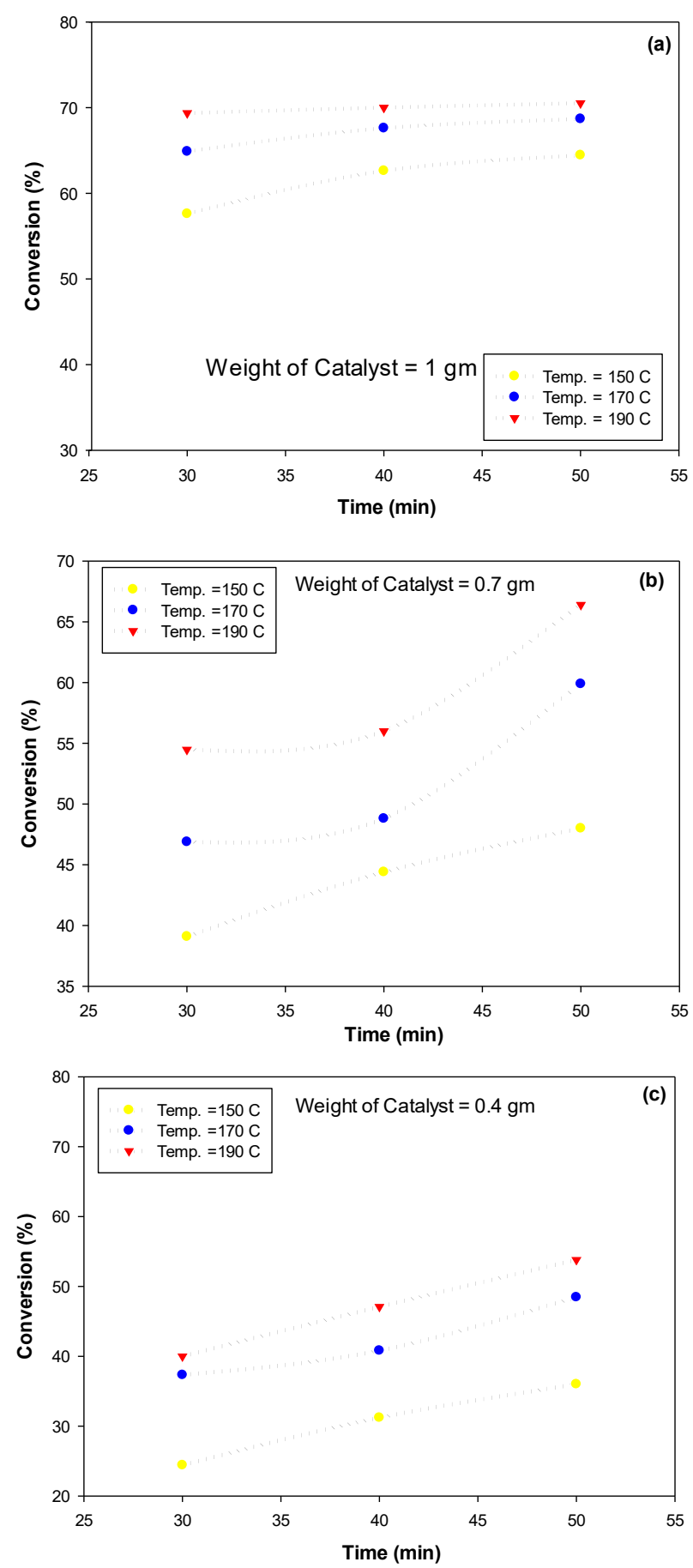

Figure 7. Effect of reaction time on sulfur removal using the prepared nano-catalyst (a) at $1 \mathrm{~g}$ and temperatures $\left(150-190^{\circ} \mathrm{C}\right)$, (b) at $0.7 \mathrm{~g}$ and temperature $\left(150-190^{\circ} \mathrm{C}\right)$, (c) at $0.4 \mathrm{~g}$ and temperature $\left(150-190^{\circ} \mathrm{C}\right)$ ment Center/Ministry of oil-Iraq by using the testing device. The pore structure parameters include pore sizes and their distribution, pore volume and surface area. Various classifications of pore sizes can be found in literature, but the International Union of Pure and Applied Chemistry (IUPAC) has classified the pores for different sizes by the following manner: micropores $>\left(20^{\circ} \mathrm{A}\right)$; mesopores $(20-500$ $\left.{ }^{\circ} \mathrm{A}\right)$; and macropores $>\left(500^{\circ} \mathrm{A}\right)$ in diameter. In general, hydrotreating catalysts are prepared by precipitation methods and the catalyst pore structure is mainly determined by the catalyst support. The pore size distribution and the total pore volume of the prepared catalyst $18 \%$ $\mathrm{ZnO} /$ nano- $\gamma-\mathrm{Al}_{2} \mathrm{O}_{3}$ has determined to be $235.7984^{\circ} \mathrm{A}$ and $0.845870 \mathrm{~cm}^{3} / \mathrm{g}$, respectively. The catalyst pore structure is also a significant issue for oxidation process of kerosene liquid due to diffusional limitations. Figure 4 shows the chemical reactions in pore size distribution.

\subsubsection{Metal dispersion (ASTM D3908)}

Figure 5 illustrates the elemental image distribution of the active component on the supported site for $18 \% \mathrm{ZnO} / \mathrm{nano}-\gamma-\mathrm{Al}_{2} \mathrm{O}_{3}$. From the results presented in this Figure, there is a good surface distribution of metal oxides (zinc) over alumina Nano particles surface giving a clear indication that the distribution of zinc oxide showed very well correspondence for oxidation desulfurization reactions. These results ensure that the precipitation is an efficient method to prepare such type of the catalyst with a good active metal distribution.

\subsection{Effect of Operating Conditions on Sulfur Removal}

In this work, the effect of the operating conditions on the oxidation process in the batch reactor was studied. All sulfur compounds were converted to sulfone then followed by sulfur conversion process as shown in Figure 6. The effect of different reaction time, reaction temperature, and several catalyst weights on sulfur removal are described.

\subsubsection{Reaction time}

An increase in the mixing time (reaction time) from 30-50 min of the oxidation process, the removal of sulfur content was increased as shown in in Figure 7a, b, and c. The maximum conversion based on the ODS reactions was found to be at $50 \mathrm{~min}$ reaction time and $190{ }^{\circ} \mathrm{C}$ (reaction temperature) with $70.52 \%$ of the sulfur removed using $1 \mathrm{~g}$ of the prepared catalyst 
$\left(18 \% \mathrm{ZnO} / \mathrm{Nano}-\gamma-\mathrm{Al}_{2} \mathrm{O}_{3}\right)$ as shown in the Figure $7 \mathrm{a}$. Increasing the reaction time leading to increase the contact time between the sulfur compounds found in the feedstock and the oxygen dissolved as well as the surface area of the prepared Nano-catalyst giving high residence time for the purpose of converting sulfur to sulfone or sulfoxide [25]. However, at long time, the observed adsorption capacities in such oxidation reactions of the trend sulfur is probably
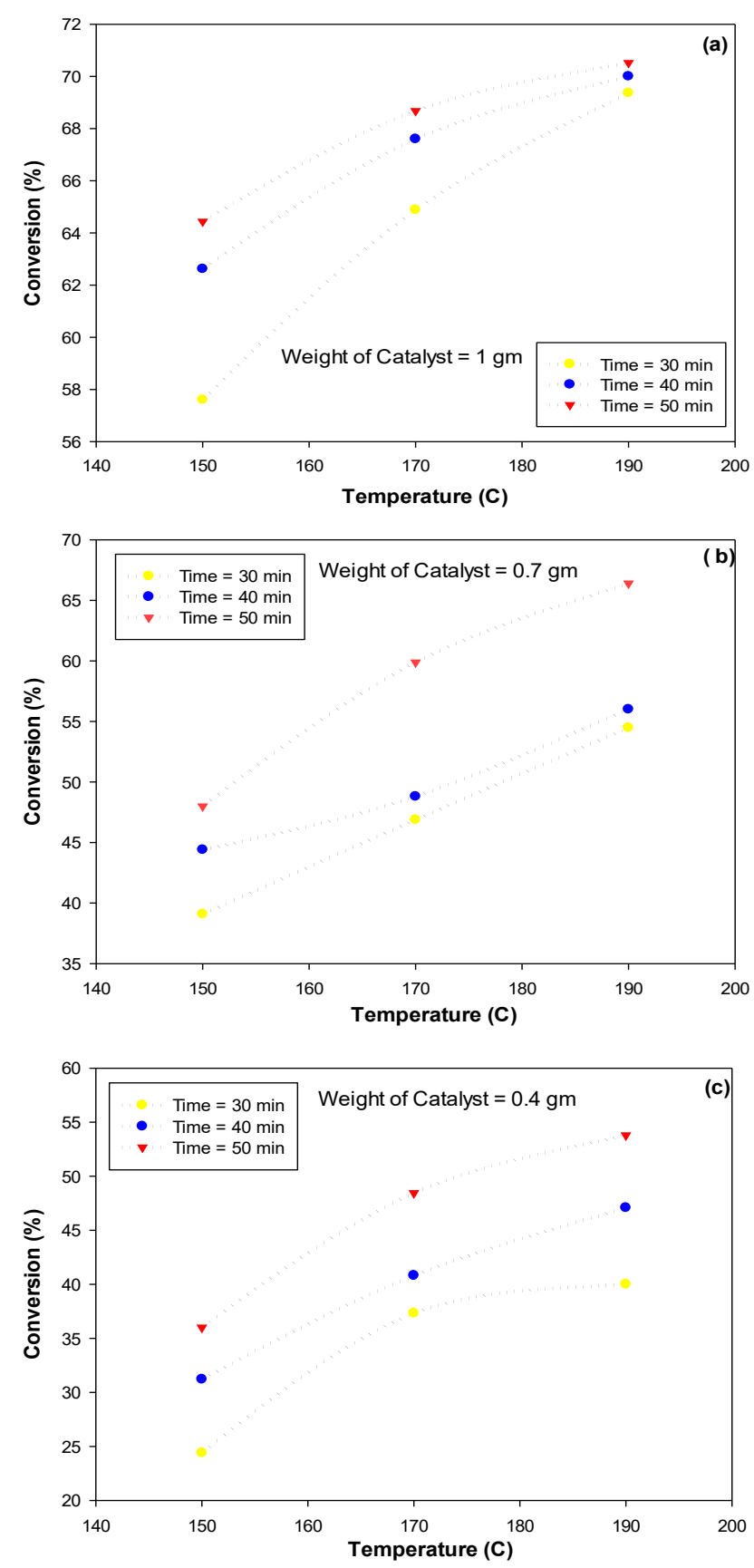

Figure 8. Effect of reaction temperature on sulfur removal using the prepared nano-catalyst (a) at $1 \mathrm{~g}$ and reaction times (30-50 $\mathrm{min})$, (b) at $0.7 \mathrm{~g}$ and reaction times (30-50 min), (c) at $0.4 \mathrm{~g}$ and reaction times (30-50 $\mathrm{min})$ reflected upon the accessible adsorption surface due to the presence of micro-meso porosity as revealed in the textural properties of the prepared catalyst $\left(18 \% \mathrm{ZnO} /\right.$ nano- $\left.\gamma-\mathrm{Al}_{2} \mathrm{O}_{3}\right)$.

\subsubsection{Reaction temperature}

Increasing the reaction temperature through oxidation desulfurization process will contribute to an increase the air dissolved in
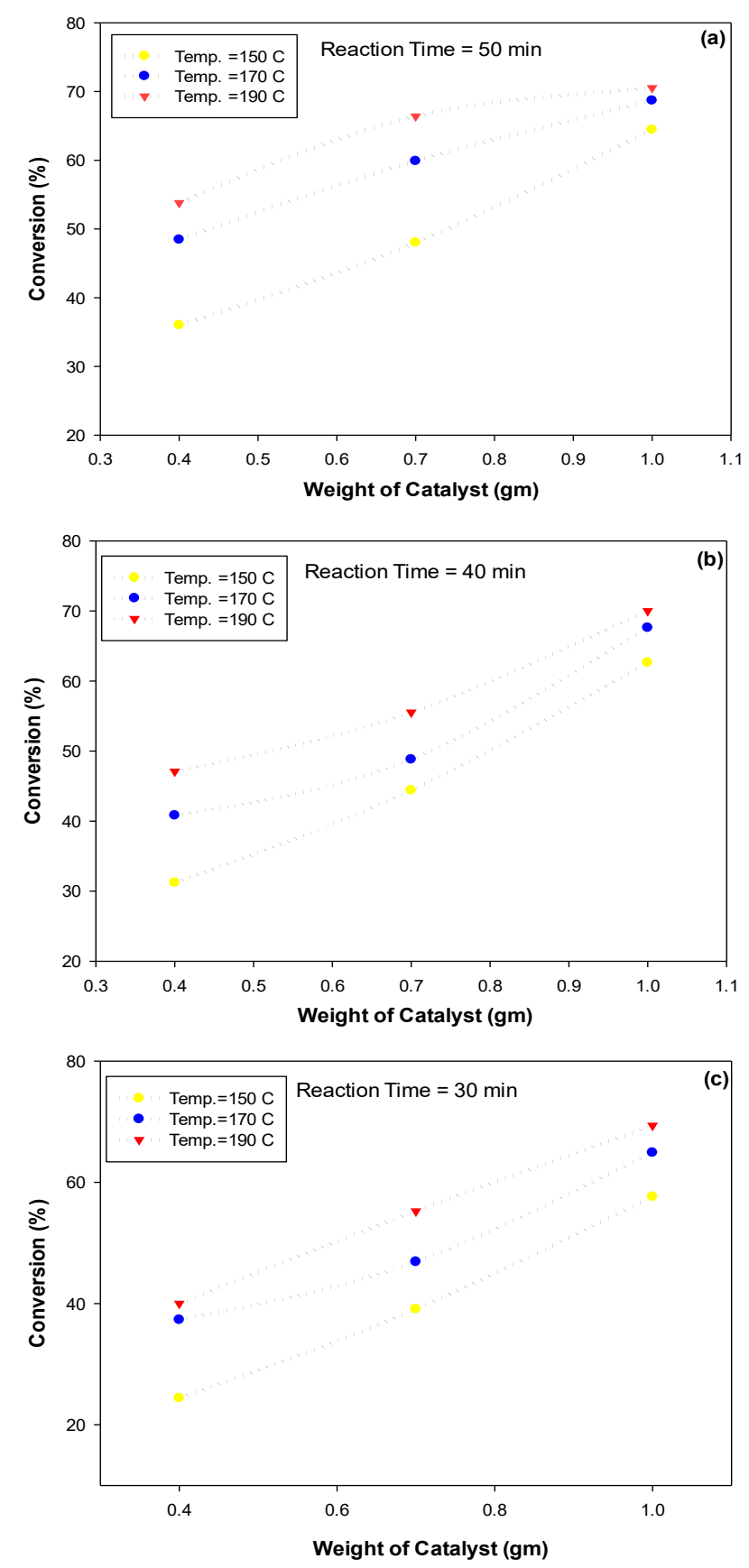

Figure 9. Effect catalyst weight on sulfur removal using the prepared nano-catalyst (a) at 50 min and temperatures $\left(150-190^{\circ} \mathrm{C}\right)$, (b) at $40 \mathrm{~min}$ and temperatures $\left(150-190^{\circ} \mathrm{C}\right)$, (c) at $30 \mathrm{~min}$ and temperatures $\left.(150-190){ }^{\circ} \mathrm{C}\right)$ 
the feedstock (kerosene) causing an increase in the chemical reaction rate within pore site of the prepared catalyst. Also, at moderate reaction temperature, an important physical properties such as diffusivity $\left(D_{A B}\right)$ and Henry's constant $(H)$ was increased with decreasing the kerosene viscosity and surface tension at the same time $[26,27]$. The impact of the reaction temperature on sulfur removal is illustrated in Figure 8a, b, and c at different reaction times and catalyst weight of $1 \mathrm{~g}, 0.7 \mathrm{~g}$, and $0.4 \mathrm{~g}$, respectively. Such behavior with respect to sulfur removal can be explained by the molecule of sulfur compound adsorbed upon the surface of the prepared catalyst $\left(18 \% \mathrm{ZnO} / \mathrm{nano}-\gamma-\mathrm{Al}_{2} \mathrm{O}_{3}\right)$

Table 6. Kinetics models results

\begin{tabular}{|c|c|c|}
\hline Order & $K\left(\mathrm{~s}^{-1} \cdot \operatorname{Con}^{1-\mathrm{n}}\right)$ & $\begin{array}{l}\text { Weight of } \\
\text { catalyst, g }\end{array}$ \\
\hline \multicolumn{3}{|c|}{ Temperature $=150^{\circ} \mathrm{C}$} \\
\hline $\mathrm{n}=1$ & 0.0246 & 1 \\
\hline $\mathrm{n}=2$ & $1.646 \times 10^{-5}$ & 1 \\
\hline \multicolumn{3}{|c|}{ Temperature $=170^{\circ} \mathrm{C}$} \\
\hline $\mathrm{n}=1$ & 0.0288 & 1 \\
\hline $\mathrm{n}=2$ & $2.1012 \times 10^{-5}$ & 1 \\
\hline \multicolumn{3}{|c|}{ Temperature $=190^{\circ} \mathrm{C}$} \\
\hline $\mathrm{n}=1$ & 0.0312 & 1 \\
\hline $\mathrm{n}=2$ & $2.448 \times 10^{-5}$ & 1 \\
\hline \multicolumn{3}{|c|}{ Temperature $=150^{\circ} \mathrm{C}$} \\
\hline $\mathrm{n}=1$ & 0.0143 & 0.7 \\
\hline $\mathrm{n}=2$ & $7.974 \times 10^{-6}$ & 0.7 \\
\hline \multicolumn{3}{|c|}{ Temperature $=170^{\circ} \mathrm{C}$} \\
\hline $\mathrm{n}=1$ & 0.0187 & 0.7 \\
\hline $\mathrm{n}=2$ & $1.1079 \times 10^{-5}$ & 0.7 \\
\hline \multicolumn{3}{|c|}{ Temperature $=190^{\circ} \mathrm{C}$} \\
\hline $\mathrm{n}=1$ & 0.0229 & 0.7 \\
\hline $\mathrm{n}=2$ & $1.48808 \times 10^{-5}$ & 0.7 \\
\hline \multicolumn{3}{|c|}{ Temperature $=150^{\circ} \mathrm{C}$} \\
\hline $\mathrm{n}=1$ & 0.0092 & 0.4 \\
\hline $\mathrm{n}=2$ & $4.444 \times 10^{-6}$ & 0.4 \\
\hline \multicolumn{3}{|c|}{ Temperature $=170^{\circ} \mathrm{C}$} \\
\hline $\mathrm{n}=1$ & 0.01397 & 0.4 \\
\hline $\mathrm{n}=2$ & $7.4483 \times 10^{-6}$ & 0.4 \\
\hline \multicolumn{3}{|c|}{ Temperature $=190^{\circ} \mathrm{C}$} \\
\hline $\mathrm{n}=1$ & 0.01612 & 0.4 \\
\hline $\mathrm{n}=2$ & $9.033 \times 10^{-6}$ & 0.4 \\
\hline
\end{tabular}

acting as adsorbent for sulfur molecules. Where, zinc oxide has showed high adsorption efficiency for different sulfur compounds owing to its high surface area based on the metal oxides.

\subsubsection{Catalyst weight}

The influence of the catalyst weight on sulfur removal during oxidative desulfurization reactions of kerosene fuel utilizing the prepared nano-catalyst at different reaction times and temperatures is presented in Figure 9a, b and c. Increasing the weight of the prepared nano-catalyst from 0.4 to $1 \mathrm{~g}$ leads to reduce the sulfur content in the kerosene products leading to increase the conversion process from $53.8 \%$ to $70.52 \%$ at $50 \mathrm{~min}$ and $190{ }^{\circ} \mathrm{C}$. These results were obtained due to the high surface area available whenever the nano-catalyst weight was increased giving high sulfur removal. Where, such surface area of the prepared nano-catalyst plays a significant role in providing more surface area of the reaction to occur. As well as, such behavior can increase the vacuum size of the pore sites leading to increase the chemical reaction rate and as a result, the sulfur molecules interaction with oxygen will increase.

\subsection{Kinetics Model for Kerosene ODS Reac- tions}

The reaction time can effect on the sulfur content in kerosene liquid fuel at different temperature. The reaction rate constants based on pseudo first and second order kinetics model have been estimated at different reaction times and temperatures. Table 6 lists the comparison between such two kinetic models (first and second order) used in the oxidation desulfurization process with several weights of the nanocatalyst $(0.4 \mathrm{~g}, 0.7 \mathrm{~g}$, and $1 \mathrm{~g})$ for the purpose of giving further insight of the process. Based on the results presented in Table 6, it has been found that the ODS reactions of kerosene fuel oil employing the prepared nano-catalyst is followed by the pseudo second order kinetic giving a good fit than pseudo first order kinetics.

\subsubsection{Activation energy of ODS process}

Depending on Arrhenius correlation, a plot of $(\ln K)$ against $(1 / T)$ will give a straight line with slope equals to $(-E / R)$ and the activation energy $(E)$ is then linearly evaluated as shown in Figure $10 \mathrm{a}, \mathrm{b}$, and c at $0.4 \mathrm{~g}, 0.7 \mathrm{~g}$, and $1 \mathrm{~g}$, respectively. The generated activation energies of the relevant reactions are introduced in Ta- 
ble 7 and such values are close to that obtained by Nawaf et al. [16,20]. It is clearly observed based on the results reported in this Table, the low amount of the prepared nano-catalyst gives higher activation energy for such reactions studied here indicating that the new nanocatalyst prepared in this work can be utilized confidently to reactor design, operation and control.
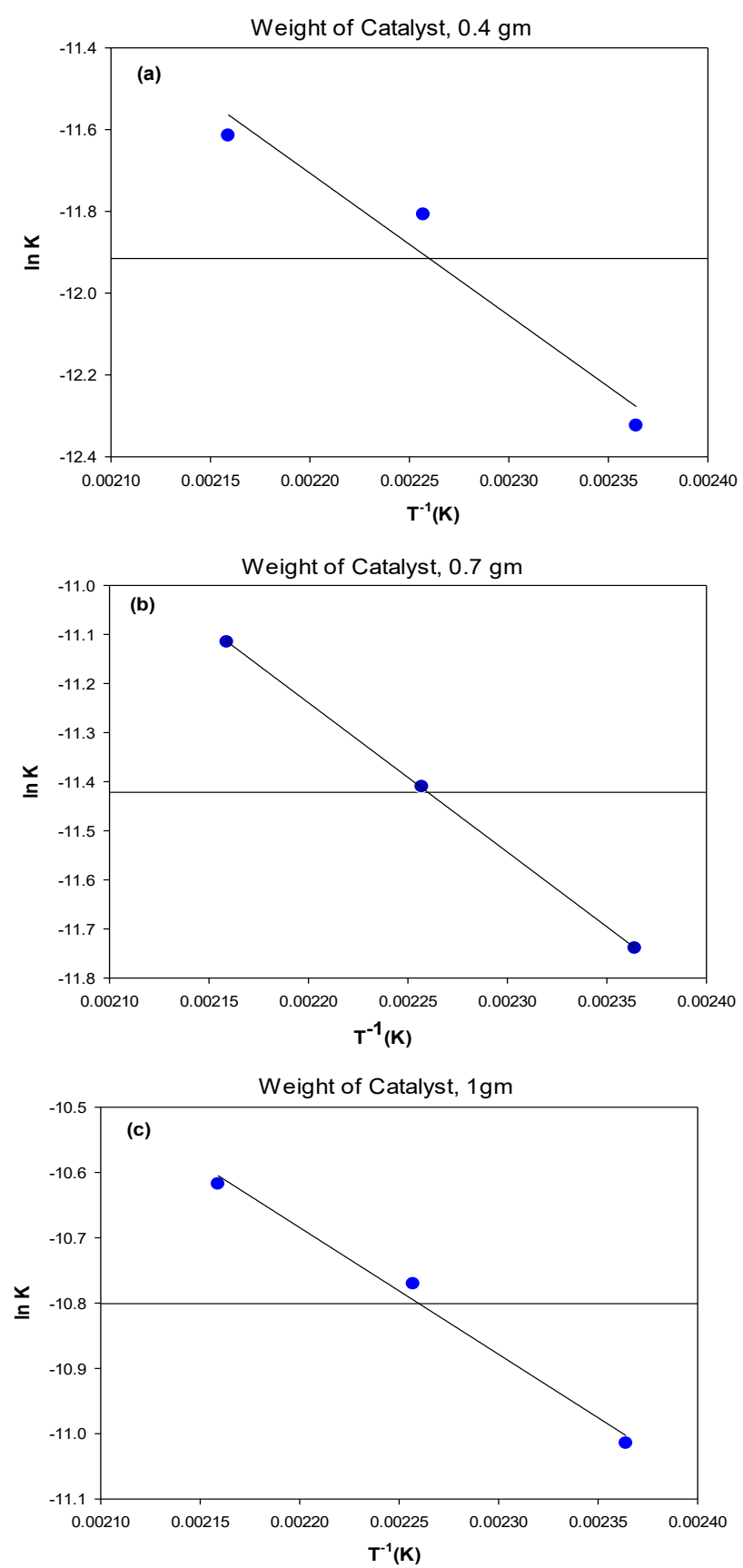

Figure 10. $\ln (K)$ ) versus (1/T) of sulfur oxidation reactions using the prepared nano-catalyst (a) at $0.4 \mathrm{~g}$, (b) at $0.7 \mathrm{~g}$, (c) at $1 \mathrm{~g}$

\subsubsection{Thiele modulus}

Tables 8 shows the results of Thiele modulus obtained here with respect to ODS reactions of kerosene using the prepared nanocatalyst at different reaction temperature and different catalyst weight. From the results of reported in this Table, it has been shown that all values of Thiele modulus (MT) for all products are less than 0.4 giving a clear indication that the effect of internal mass transfer on the overall oxidation rate can be neglected. Such results could be attributed to the small size of the particle making the pore diffusion resistance very small.

\subsection{Simulation Results}

For further insight of the ODS process, simulation results employing the kinetic model proposed in this study based on the nanocatalyst prepared are required. The comparison results between experimental and model predicted data for ODS of kerosene utilizing the prepared nano-catalyst over a wide range of the operating conditions investigated in this work, are shown in the Figure 11a, b, c, and d. As clearly seen from these Figure, process simulation results have found to agree well with the experiments conducted in a wide range of the studied operating conditions (different catalyst weights, several reaction times and temperatures). Such agreement indicated that the model can be applied confidently for other operations. Thus, the nil content of sulfur compound based on the optimal design and operation of such process is a worthy subject for future study.

\section{Conclusions}

Sulfur removal by air of kerosene fuel in a batch reactor based on the new nano-catalyst $\left(18 \% \mathrm{ZnO} /\right.$ nano- $\left.\gamma-\mathrm{Al}_{2} \mathrm{O}_{3}\right)$ prepared in this study can successfully be achieved. Oxidative desulphurization process (ODS) appears to be technically and economically available for processing ultra-low sulfur fuel. It can be considered as an alternative process in comparison with

Table 7. Activation energies of the prepared nano-catalysts

\begin{tabular}{cc}
\hline $\begin{array}{c}\text { Weight of } \\
\text { Catalyst, } \mathrm{g}\end{array}$ & $\begin{array}{c}\text { Activation energy, } \\
\mathrm{kJ} / \mathrm{mole}\end{array}$ \\
\hline 0.4 & 28.9402 \\
0.7 & 25.3095 \\
1 & 16.1449 \\
\hline
\end{tabular}




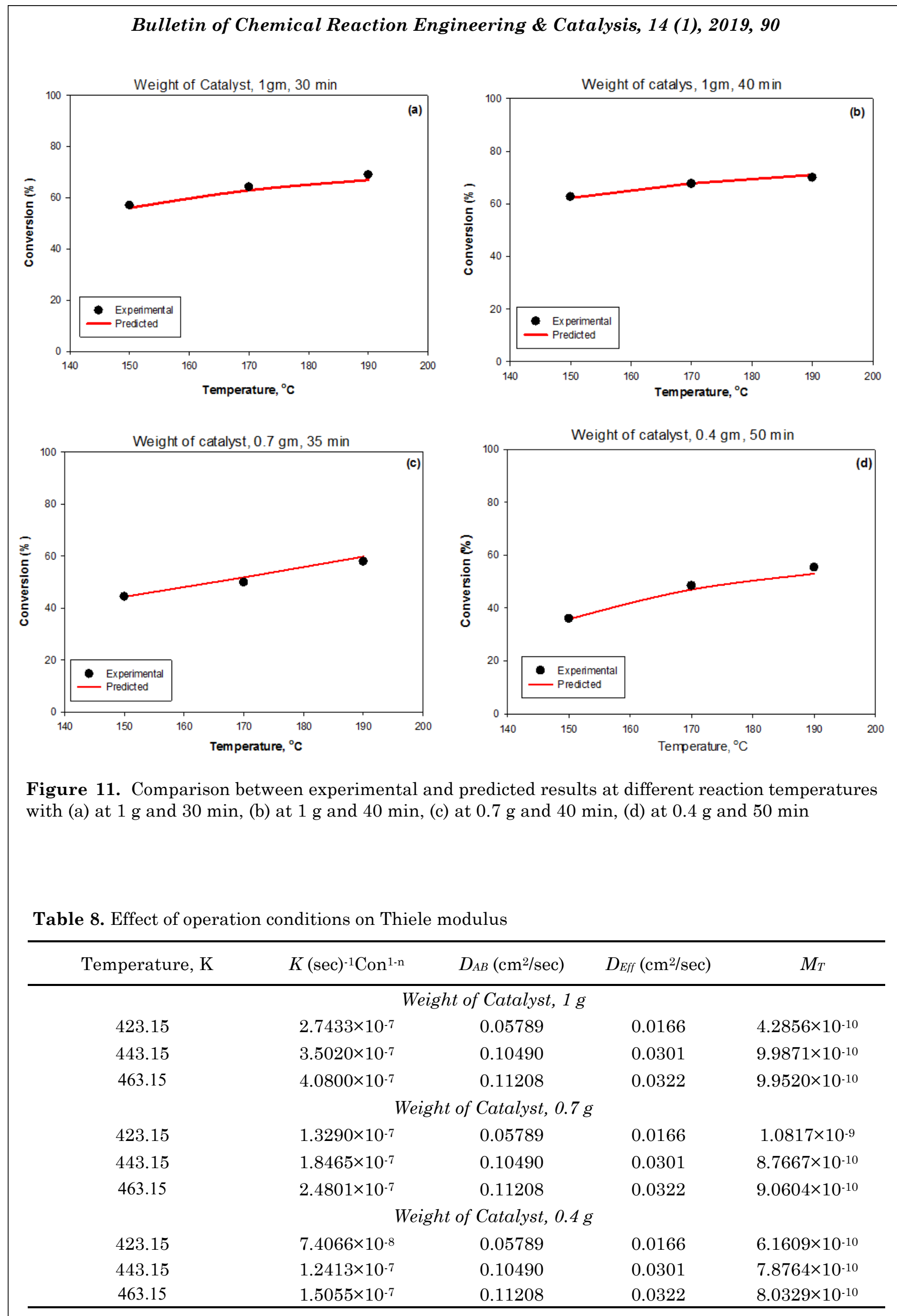


the conventional hydrodesulfurization process (HDS). Notably, ODS does not require hydrogen (only air) as presented by HDS process in addition to its capital cost and operating cost that would significantly be lower than HDS process (further studies will be investigated in future).

The oxidative desulfurization process using the new catalyst showed that the chemical reactions can be carried out under moderate reaction temperature with very short reaction time. Also, the air can be used as an efficient oxidant based on the new nano-catalyst prepared in this study compared with other costly oxidants, mainly $\mathrm{H}_{2} \mathrm{O}_{2}$, ozone and TBHP (reported in the literatures for ODS processes). Second order kinetics model have been obtained for ODS reaction and it can be used to represent the system. The effect of internal mass transfer can be neglected.

\section{Nomenclatures}

$r_{\text {sulfur }}$ : Sulfur rate of reaction

$V_{\text {Batch }}:$ Reactor volume, $\mathrm{cm}^{3}$

$C_{\text {sulfur }}$ : Sulfur concentration, ppm

$t \quad:$ Reaction time, min

$K \quad$ : Kinetic rate constant, (time) $)^{-1}(\text { conc.) })^{1-n}$

$M_{T} \quad$ : Thiele modulus

$n \quad$ : Order of reaction

$D_{E f f}$ : Effective Diffusivity Coefficient, $\mathrm{cm}^{3} / \mathrm{cm}$ solid. sec

$D_{A B} \quad$ : Molecular Diffusion Coefficient, $\mathrm{cm}^{3} / \mathrm{sec}$

$E \quad$ : Activation energy, $\mathrm{kJ} / \mathrm{mol}$

$L \quad$ : Characteristic length of the catalyst, $\mathrm{cm}$

\section{Greek Letters}

$\tau_{P} \quad$ : Tortuosity of the nano-catalyst pores

$\epsilon_{P} \quad$ : Porosity of the nano-catalyst particles

$\gamma \quad$ : Gamma

\section{References}

[1] Babich, V.I., Moulijn, A.J. (2003). Novel Processes for Deep Desulfurization of Oil Refinery Streams. Fuel, 82: 607-631.

[2] Rang, H., Kann, J., Oja, V. (2006). Advances in desulfurization research of liquid fuel. Oil Shale, 23: 164-176.

[3] Zhang, X.H., Gao, J.J., Meng, H., Lu, Z.Y., Li, X.C. (2012). Catalytic Oxidative Desulfurization of Fuel by $\mathrm{H}_{2} \mathrm{O}_{2}$ In Situ Produced via Oxidation of 2-Propanol. Ind. Eng. Chem. Res. 51: 4868-4874.

[4] Sundararaman, R., Ma, X., Song, C. (2010). Oxidative desulfurization of jet and diesel fuels using hydroperoxide generated in situ by catalytic air oxidation. Ind. Eng. Chem. Res. 49: 5561-5568.

[5] Zannikos, F., Vignier, V. (1995). Desulphurization of petroleum fractions by oxidation and solvent extraction. Fuel Proc. Tech. 42: 35-45.

[6] Rappas, S.A., Nero, P.V., DeCanio, J. S. (2002). Process for removing low amounts of organic sulphur from hydrocarbon fuels, US Patent 6, 402, 940 B1, 1-7.

[7] Ma, X., Zhou, A., Song, C. (2007). A novel method for oxidative desulfurization of liquid hydrocarbon fuels based on catalytic oxidation using molecular oxygen coupled with selective adsorption. Catal. Today. 123: 276284.

[8] Al-Malki, A. (2004). Desulfurization of Gasoline and Diesel Fuels Using Non-Hydrogen Consuming Techniques. M.Sc. Thesis: King Fahad University of Petroleum and Minerals: Saudi Arabia.

[9] Dishun, Z., Fengxia, S., Erpeng, Z., Yan, L. (2003). A Review of Desulfurization of Light Oil Based on Selective Oxidation. Chemical Journal on Internet, 6: 17-23.

[10] Breysse, M., Diega-Mariadassou, G., Pessayre, S., Geantet, G., Vrinet, M., Lemaire, M. (2003). Deep desulfurization: reactions, catalysts and technological challenges. Catal. Today, 84: 129-138.

[11] Mohammadbeigi, K., Tajerian, M. (2004). Demercaptanization of distillate (DMD). $\mathrm{Pe}$ troleum \& Coal, 46: 17-22.

[12] Chica, A., Corma, A., Domine, E.M. (2006). Catalytic oxidative desulfurization (ODS) of diesel fuel on a continuous fixed-bed reactor. J. Catal. 242: 299-308.

[13] Ma, X., Zhou, A., Song, C. (2007). A novel method for oxidative desulfurization of liquid hydrocarbon fuels based on catalytic oxidation using molecular oxygen coupled with selective adsorption. Catal. Today, 123: 276284.

[14] Sampanthar, T.J., Rong, X., Dautzenberg, M.F. (2013). Desulfurization of liquid fuels using air-assisted performic acid oxidation and emulsion catalyst. Chinese Journal of Catalysis 34: 1839-1847.

[15] Jarullah, A.T., Mujtaba, I.M., Alastair, S.W. (2011). Kinetic parameter estimation and simulation of trickle-bed reactor for hydrodesulfurization of crude oil. Chem. Eng. Sci. 66: 859-871.

[16] Nawaf, A.T., Gheni, S.A., Jarullah, A.T., Mujtaba, I.M. (2015). Optimal Design of a Trickle Bed Reactor for Light Fuel Oxidative Desulfurization Based on Experiments and Modeling. Energy \& Fuels, 29: 3366-3376. 
[17] Zeki, A.S.N., Ali, M.S., Al-Karkhi, R.S. (2017). Investigation Desulfurization Method Using Air and Zinc Oxide/Activated Carbon Composite. Iraqi J. Chem. Pet. Eng. 18: 37-46.

[18] Hernandez, P.S., Chiappero, M., Russo, N., Fino, D. (2011). A novel ZnO-based adsorbent for biogas purification in $\mathrm{H}_{2}$ production systems. Chem. Eng. J. 176: 272-279.

[19] Levenspiel, O. (1999). Chemical Reaction Engineering. Third ed. John Wiley \& Sons, Inc.: New York.

[20] Nawaf, A.T., Jarullah, A.T., Gheni, S.A., Mujtaba, I.M. (2015). Development of Kinetic and Process Model for Oxidative Desulphurization of Light Fuel using Experiments and Parameter Estimation Technique. Ind. Eng. Res. 54: 12503-12515.

[21] Leyva-Ramos, R.C., Geankoplis, J. C. (1994). Diffusion in Liquid Filled Pores of Activated Carbon. I. Pore Volume Diffusion. Chem. Eng. 72: $262-271$

[22] Tang, M.J., Kalberer, M. (2015). Supplement of Compilation and evaluation of gas phase diffusion coefficients of reactive trace gases in the atmosphere: Volume 2. Diffusivities of organic compounds, pressure-normalised mean free paths, and average Knudsen numbers for gas uptake calcu. Atmos. Chem. Phys. 15: 5585-5598.
[23] Bird, R.B., Stewart, W.E. (2002). Transport Phenomena, Second ed. John Wiley \& Sons, Inc.: New York.

[24] Jo, J., Baek Lee, S., Mok, S.Y. (2017). Effect of Calcination Temperature Of $\mathrm{Mn}_{\mathrm{x}} \mathrm{O}_{\mathrm{y}} / \gamma-\mathrm{Al}_{2} \mathrm{O}_{3}$ catalyst On Ozone Decomposition. Research World International Conference, Poland, 5-8.

[25] Saleh, A.T., Sulaiman, O.K., AL-Hammadi, A.S., Dafalla, H., Danmaliki, I.G. (2017). Adsorptive desulfurization of thiophene, benzothiophene and dibenzothiophene over activated carbon manganese oxide nanocomposite: With column system evaluation. Cleaner Prod. 17: 959-6526.

[26] Chan, K., Jung, J., Lee, J., Sang, B., Kyungil, C., Sang, H. (2000). Hydrodesulphurization of DBT, 4- MDBT, and 4,6-DMDBT on fluorinated $\mathrm{CoMoS} / \mathrm{Al}_{2} \mathrm{O}_{3}$ catalysts. Appl. Catal. A, 200: 233-242.

[27] Nawaf, A.T., Gheni, S.A., Jarullah, A.T., Mujtaba, I.M. (2015). Improvement of Fuel Quality by Oxidative Desulfurization: Design of Synthetic Catalyst for the Process. Fuel Proc. Tech. 138: 337-343. 